\title{
Job-shop Scheduling Approach to Order-picking Problem*
}

\author{
Yukiyasu IwaSAKI $^{\dagger}$, Ikuo SuzukI ${ }^{\ddagger}$, Masahito YAmamoto ${ }^{\dagger}$ and Masashi FurukawA ${ }^{\dagger}$
}

\begin{abstract}
In recent years, a large-scale logistic center plays an important role in mail-order business with Internet. In the logistic center, the efficient managing is required to deliver products to customers as soon as possible. Researches to efficiently control the logistic center have been done in the various approaches. This study proposed a new method for the order-picking problem considering worker's jamming at the same shelf in the logistic center. In the proposed method, we formulate worker's scheduling in the logistic center as Job-shop Scheduling Problem and optimize this problem. Numerical experiments show the proposed method improve worker's scheduling compared with rulebased scheduling.
\end{abstract}

\section{Introduction}

Rapid spreading of mail-order shopping, on-line shopping and supply chain systems requires largescale logistic centers. Now, anyone can shop and order products at any place in the world through Internet. A logistic center has various functions such as not only keeping products but also shipping products. Fig. 1 shows functions in the logistic center from a customer's order to shipment.

For shipping products, it becomes important to make good plans to collect products ordered by customers as fast as possible because of due date. Such plans in the logistic center are assigning order-sheets to workers, who collect products under the specified order-sheets, finding an efficient route to drop in shelves and pick products, sorting collected products under the order-sheets, packing sorted products to deliver the same district, and making a shipping schedule for trucks. A work of collecting products at the logistic center is called an order-picking work. Making a series of plans for assigning order-sheets to workers, dropping in shelves and picking products called an order-picking problem. More than $80 \%$ of logistic centers in Western Europe adopt the order-picking work. We have already tackled the order-picking problem by formulating it as a traveling salesman problem to determine a collecting products route for workers.

In this paper, we propose a new solution for the

* Manuscript Received Date: June 1, 2012
+ Graduate School of Information Science and Technol-
ogy, Hokkaido University; Kita 14 Nishi 9, Kita ward,
Sapporo city, Hokkaido 060-0814, JAPAN
₹ Department of Computer Science, Kitami Institute of
Technology; 165 Koencho, Kitami city, Hokkaido 090-
8507, JAPAN
Key Words: combinational optimization, scheduling, Key Words: combinational optimization
logistic center, local clustering organization

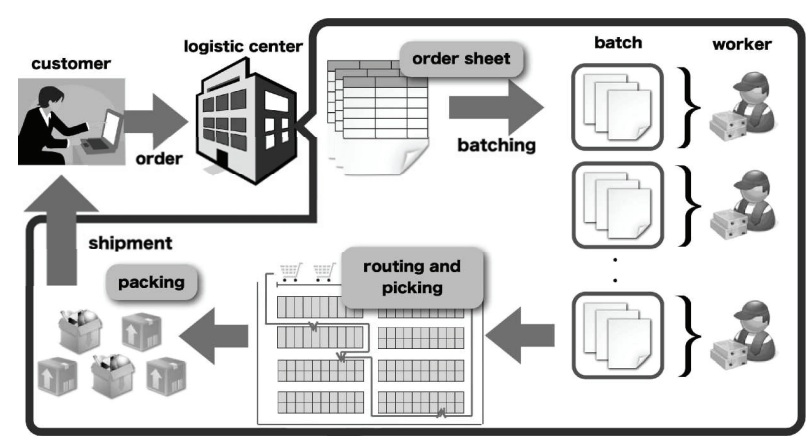

Fig. 1 Activities in logistic center

order-picking problem, which takes consideration into jamming of workers at the same shelves. The new solution is based on one applied to the job-shop problem. The paper is composed of as follows. After the introduction, some related works are explained. Then, the research purpose is described. Since we deal with the order-picking problem as the job-shop scheduling problem, the job-shop scheduling problem is concisely introduced and it is reformulated orderpicking problem, which takes into consideration in worker's jamming in the logistic center. Before we show results of numerical experiments, a model of a logistic center is explained and ordered product properties for this model is shown from a viewpoint of real management of the warehouse. Numerical experiments verify that the proposed method can efficiently manage the warehouse. Finally, we summarize our study with some remarks.

\section{Rerated Works and Purpose}

The order-picking problem consists of three major decision-making problems: (1) how order-sheets are combined and assigned to workers, (2) how workers make the shortest route plan to collect products specified by given order-sheets, (3) how products are 
assigned to shelves in a logistic center.

There are few researches on the first problem. The second problem is treated as a vehicle routing problem or an n-traveling salesman problem (n-TSP). We have applied Heuristics or Meta heuristics to the second problem $[1,2]$.

Many researches have been done for the third problem. M.K. Liu[3] proposed a clustering technique for product stock-allocation and order-picking. He formulated the problem as an assignment one and developed a primal-dual heuristic algorithm by rewriting the problem as the dual problem. However, this clustering algorithm is only applicable for a rectangular warehouse, where racks are arranged as columns and the columns are allocated to be parallel each other. This allocation makes it possible to formulate the problem as the assignment problem. Since grouped columns are not allocated merely to be rectangular shape, this algorithm is not applicable for the order-picking problem. M. B. Rosenwein[4] and J. M. Jarvis[5] were using a similar model as C. M. Liu. R. K. Koster, T. Le-Duc and K. J. Roodbergen[6] survey and review many literatures for order-picking. They illustrate " Class-based storage" , " Zoning " and " Batching", and " Routing methods". However, a model used by them is the rectangular warehouse as seen in C. M. Liu. The actual warehouse is much more sophisticated than they used. L. C. Tang and E. P. Chew[7] propose a batching algorithm for products based on the queuing theory and its result was applied for storage assignment. They also considered a picking system in a rectangular system. C. G. Peterson and R. W. Schmenner[8] evaluated routing and volume-based storage policies in an order picking operation. They indicated some geometric patterns for a warehouse to stock products based on ordered product volumes. They insisted that the ordered product with the largest volume should be allocated near a picking and dropping point (an exit point) in the warehouse. In the related works, they have focused on only the moving distance to workers and proposed effective methods for product allocation or routing. However, we need to consider worker's activity in the actual logistic center because many of these studies have been simulated without considering the jammed situation by many workers. The jammed situation means that workers attempt to pick the same product at the many same time at the same shelf. In this study, we consider the jammed situation.

Simultaneously working on the same shelf affects the management of collecting remaining products or work space such as picking cart gang ways. For example, if there is other worker is picking when the worker arrives at the same shelf, the worker who comes later have to wait until the former worker picking. Furthermore, if there are waiting workers, the worker who come last has to wait until after all workers would finish picking. At this time, the workers who come last and wait has better to replan the next picking sequence of products. This makes a new extra traveling path and becomes more complex because we must make a schedule that involves many workers' plans.

In this study, the order-picking problem including such a jamming conditions is replaced by Job-shop Scheduling Problem (JSP) and Local Clustering Organization (LCO) is applied to solve JSP.

\section{Job-shop Scheduling Problem}

\subsection{Job-shop Scheduling Problem}

JSP is a typical combinatorial optimization problem often applied in manufacturing systems. This problem is composed of a set of $\mathrm{n}$ jobs $J=\left\{J_{q}\right\}, q=$ $1,2, \cdots, n)$ and a set of $\mathrm{m}$ machines $M=\left\{M_{r}\right\}, r=$ $1,2, \cdots, m$. Each job $J_{q}$ has their process and the sequence to use the machine $M S_{q}=\left(M q r_{1}, M q r_{2}, \cdots\right.$, $\left.M q r_{m}\right)$ which has already been decided. Furthermore, a processing time of the machine to be used in the process of each job is given. In addition, the sequence of machines is restricted. Solution must satisfy that more than two jobs cannot be processed at the same machine simultaneously. The purpose of this problem is finding a feasible schedule that minimizes the makespan, namely the total elapsed time. The total number of combinations increases exponentially when the number of job and machine becomes large and the problem belongs to the NP hard class. In this study, solution expression of JSP is used multi-gene such as Fig. 2.

\begin{tabular}{|l|l|l|l|l|l|l|l|l|l|l|l|}
\hline $\mathrm{J}_{1}$ & $\mathrm{~J}_{2}$ & $\mathrm{~J}_{4}$ & $\mathrm{~J}_{4}$ & $\mathrm{~J}_{3}$ & $\mathrm{~J}_{4}$ & $\mathrm{~J}_{1}$ & $\mathrm{~J}_{2}$ & $\mathrm{~J}_{3}$ & $\mathrm{~J}_{1}$ & $\mathrm{~J}_{2}$ & $\mathrm{~J}_{3}$ \\
\hline
\end{tabular}

Fig. 2 The solution expression by multi-gene

\subsection{Solution of JSP}

A solution of a JSP is to assign job sequences to machines shown in Fig. 2. To represent such job assignments and sequences, we use the multiple gene representation. At first, we prepare one-dimensional array, which stores $n \times m$ data. The job number $J_{1}$ is stored in the first $m$ data of the array, then $J_{2}$ is stored from $(m+1)-t h$ data to $2 m-t h$ data, and so on. Finally $J_{n}$ is stored from $(n m-1)-t h$ data to $n m-t h$ data. After that, the data is rearranged in the array. The sequence of the rearranged data becomes the solution of the JSP. Fig. 3 shows an example of the rearranged data. Let us assume that $J_{1}, J_{2}$, and $J_{3}$ have processing sequence as shown in Table 1 . Then, the first data in the array $J_{1}$ is assigned to the first processing of machine $M_{1}$ by referring Table 1 , the second data in the array $J_{2}$ is assigned to the first processing of machine $M_{3}$ by referring Table 1 , the third data in the array $J_{4}$ is assigned to the first processing of machine $M_{2}$ by referring Table 1 , and the forth data in the array $J_{4}$ is assigned to the second processing of machine $M_{1}$ by referring Table 1 . This 


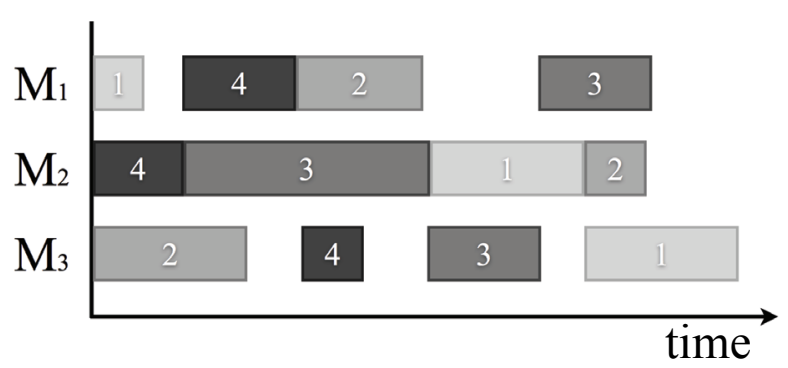

Fig. 3 The gantt chart

Table 1 An example of problem

\begin{tabular}{|l|l|l|l|}
\hline$J_{1}$ & $M_{1}$ & $M_{2}$ & $M_{3}$ \\
\hline$J_{2}$ & $M_{3}$ & $M_{1}$ & $M_{2}$ \\
\hline$J_{3}$ & $M_{2}$ & $M_{3}$ & $M_{1}$ \\
\hline$J_{4}$ & $M_{2}$ & $M_{1}$ & $M_{3}$ \\
\hline
\end{tabular}

procedure is repeated by the last data of the array assigned to some machine. Fig. 3 is obtained in this way in consideration of avoiding overlapped processing time of jobs.

\subsection{Order Picking Problem}

In an order-picking problem (OPP), $n$ workers travels $m$ shelves, which is specified by given order sheets in a logistic center. The worker leaves from the depot with a cart. When he comes and stands at some shelf, he picks up the specified number of product and put them into his cart. This working time is called the picking time. Then he moves to another shelf. When he collects all products specified by the order sheets, he returns to the depot. All the time that he spends for this traveling tour becomes his make-span time for his task. $n$ workers repeat this collecting task. When all order sheets are assigned to $n$ workers and $n$ workers completely finish their tasks at $K$ times, the longest cumulated traveling time of the the worker in $K$ times becomes the maximum make-span time for the OPP. OPP is to find how to assign order sheets to workers repeatedly and how to travel shelves so as to minimize the maximum makespan time.

However, most of researches on the OPP merely determine an efficient traveling tour path between shelves. As described in the previous section, workers jamming frequently happen at the same shelf and this disturbs the efficient traveling tour. This paper treats OPP with the jamming restriction.

\section{Transformation of OPP to JSP}

4.1 Mathematical Expression of OPP

The OPP is formulated as follows.

$$
\begin{aligned}
& \text { minimize } T=C_{\max } \\
& \text { subject to } C_{\max }=\max \left(C_{1}, C_{2}, \cdots, C_{n}\right)
\end{aligned}
$$

$$
\text { and } C_{i}=\sum_{k=1}^{K} W_{i k}+\sum_{k=1}^{K} T_{i k}+\sum_{k=1}^{K} P_{i k}
$$

where $K$ is the number of traveling tours, $W_{i k}$ is the cumulated waiting time for picking in the $k$-th tour, $T_{i k}$ is the traveling time in the $k$-th time, and $P_{i k}$ is the cumulated picking time in the $k$-th tour. $C_{i}$ is the cumulated make-span time of the the worker $i$ in $K$ times. The worker $i$ is specified shelves, where he picks products given by the assigned order sheets, in $k$-th tour. We set the task $O_{i k}$ as the order sheets given to the worker $i$ in the $k$-th tour. Then the worker $i$ completes the task specified by a set of tasks $O_{i}$ in turn $K$ times, where

$$
O_{i}=\left\{O_{i 1}, O_{i 2}, \cdots, O_{i K}\right\}
$$

$O_{i k}$ determines products and shelves where the worker $i$ must pick the products. We have to seek a tour sequence of shelves for the worker $i$ as short as possible in $k$-th tour. This problem becomes a travelling salesman problem (TSP). This traveling time becomes $T_{i k}$. Let us assume that there are $n_{i}(k)$ shelves for the worker $i$ in $k$-th tour. Once we solve the TSP, we have the precedence relation of shelves that the worker $i$ drops in the $k$-th tour. We write this precedence relation of shelves as

$$
\begin{aligned}
& R\left(S_{i k}\right)=\left(s_{i 1 k}<<s_{i 2 k}<<\cdots<<s_{i n(k)}\right) \\
& S_{i k}=\left\{s_{i 1 k}, s_{i 2 k}, \cdots, s_{i n(k)}\right\}
\end{aligned}
$$

where $s_{i j k}$ is the $j$-th shelf that the worker $i$ drops in the $k$-th tour.

If other worker is picking products when the worker $i$ arrives at the shelf $s_{i j k}$, he must wait for finishing his picking operation. This time is defined as the waiting time at the shelf $s_{i j k}$ for the worker $i$ in $k$-th tour. Then the waiting time $W_{i k}$ is written as

$$
W_{i k}=\sum_{j=1}^{n(k)} W_{i j k}
$$

This waiting time represents the workers' jamming time. In conventional order-piking method, the waiting time is not taken consideration in scheduling.

\subsection{Transformation of JSP to OPP}

Now, OPP is transformed to JSP. We regard a set of tasks $O_{i}$ and a set of shelves $S_{i k}$ for the worker $i$ in $k$-th tour as a set of jobs $J$ and a set of machines $M$ respectively. Job' s precedence relation $M S_{q}$ is replaced with $R\left(S_{i k}\right)$. The machining time in JSP is replaced with the picking time in OPP. The waiting time for machining in JSP is replaced with

$$
\max \left(t\left(s_{i, j-1, k}, s i, j 1, k\right), w_{i j k}\right)
$$

where $t\left(s_{i, j-1, k}, s_{i, j 1, k}\right)$ is the tour time from the shelf $s_{i, j-1, k}$ to the shelf $s_{i, j 1, k}$. This relation is shown in Table 2 . 
Table 2 Comparison order-picking with JSP

\begin{tabular}{|c|c|}
\hline Order-picking & JSP \\
\hline Order & Job \\
\hline Shelf & Machine \\
\hline Sequence of picking products & Process sequence \\
\hline Picking time & Machining time \\
\hline
\end{tabular}

Differences of OPP fro JSP is as follows:

(1) The number of shelve for the worker $i$ in OPP always changes. In JSP, the number of machines is constant.

(2) Shelve that each task for the worker use are different ( in some case, duplicated ) in OPP. In JSP, all jobs uses all machines.

(3) In OPP, the waiting time includes the tour partially as shown eq. (7).

\section{Solving Order-picking Problem as Job-shop Scheduling Problem}

In the previous section, it is described how OPP is transformed to JSP. This section explain how OPP is solved as JSP.

\subsection{Assignment of Order Sheets to Workers}

At first, order sheets for one-day operation in a logistic center is assigned to workers as shown in eq. (4). We assign the same number of order sheet to the workers. The order sheets $O_{11}$ is assigned to the worker 1 , the order sheets $O_{21}$ is assigned to the worker 2, and this is repeated till the order sheets $O_{n 1}$ is assigned to the worker $n$. When the worker 1 finishes his task and return to the depot, the order sheet $O_{12}$ is assigned to the worker 1 . So is the workers 2,3 , and so on. In this way, the workers task given by eq. (4) is determined.

\subsection{Determination of Picking Route and Shelf Precedence Relation}

The order sheets $O_{i k}$ for the $k$-th task for the worker $i$ specify the dropping shelves in the $k$-th tour for the worker $i$. We regard a depot in a logistic center as a starting city and returning city in TSP. Also, we regard a set of shelves specified by $O_{i k}$ for the $k$ th task as a set of cities in TSP. Paths between the depot and the shelves and between shelves make a weighted network graph. We set a distance between two neighborhood shelves that has a path between them to a weight value of the network graph. When the set of shelves used in the $k$-th tour is given, we calculate the shortest path between two shelves on the network by use of Dijkstra method. Now, the cumulated distances along the shortest path between two shelves can be calculated and this distance becomes two cities' distance, namely, the cost, in TSP. After the set of shelves and their cost between two shelves are determined, TSP is completely described.

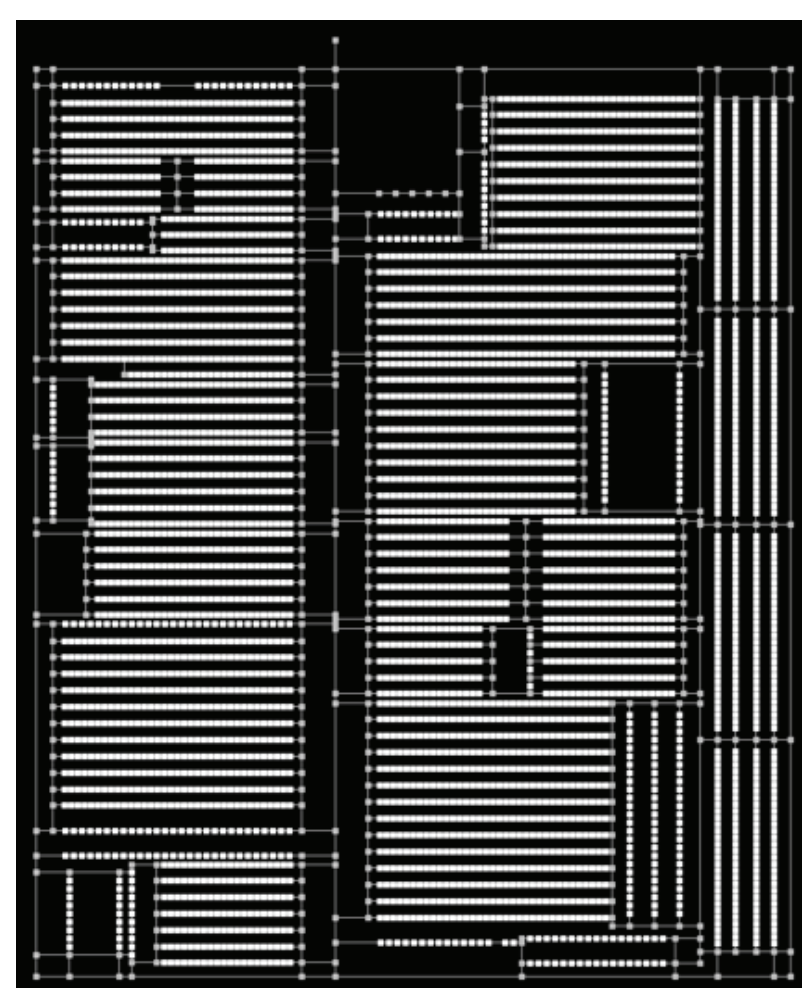

Fig. 4 Logistic center model

We solve this TSP by use of Local Clustering Organization (LCO), which is capable of solving large-scale TSP in a short time [9]. The solution of TSP gives a sequence of shelves that worker i makes a tour to collect products. This sequence becomes the shelf precedence relation $R\left(S_{i k}\right)$ in eq. (5).

\subsection{Solving OPP as JSP}

Once the precedence relation $R\left(S_{i k}\right)(i=1,2, \cdots, n)$ for workers and the cost between two shelves used in the $k$-tour, we can solve this problem as JSP. Since LCO is capable of solving not only TSP but also JSP [10], LCO is applied to solve this JSP. In the proposed method, JSP is solved and obtained solution becomes OPP one. When the worker finishes the $k$-th tour, the worker can start the $(k+1)$-th tour before other workers finish the $k$-th tour.

\section{An Experimental Model of a Lo- gistic Center}

In this study, we use the logistic center model as shown in Fig. 4.

In Fig. 4, we place nodes in front of the shelves and consider nodes as a picking point. We connect link between nodes as passage, and set intersection points in links as picking points. The cost between nodes is an actual distance and workers move on the passage at a constant speed. A start and goal point is the same location. This model is the real logistic center and we use the real data for order sheets. Capability of this logistic center model and the order-sheet data are shown in Table 3. 
Table 3 Experiment condition of logistic center model and order-sheet data

\begin{tabular}{|l|r|}
\hline Parameter & Value \\
\hline The number of order sheet & 9447 \\
\hline The number of shelves & 4305 \\
\hline The number of kind of products & 7003 \\
\hline The speed of a worker [m/sec] & 1 \\
\hline n-Picking time [sec] & $30+3 \times \mathrm{n}$ \\
\hline
\end{tabular}

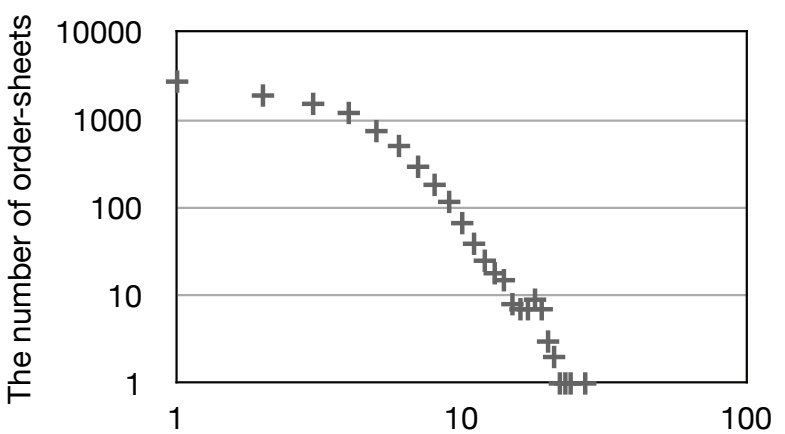

The number of kind of products in one order-sheet

Fig. 5 The number of kind of products per one order sheets

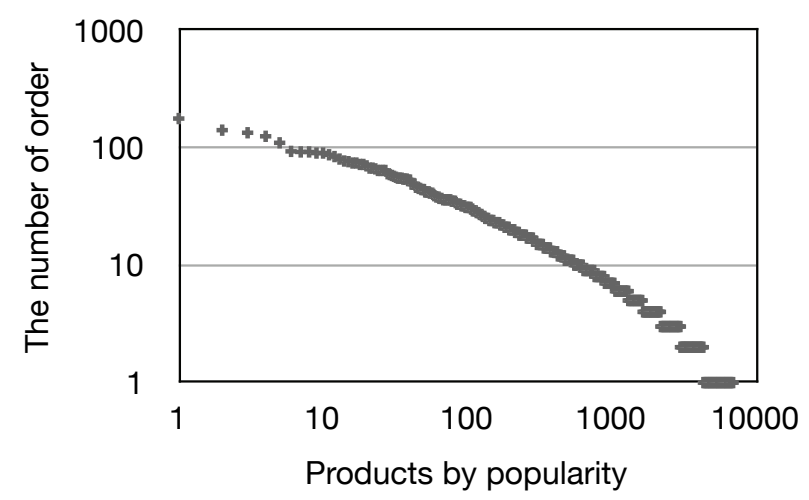

Fig. 6 The number of kind of products and the number of ordered

Fig. 5 shows the distribution on the number of kinds of products in a single order sheet, that is what kind of products are ordered per one order. According to Fig. 5, the order sheet that specifies only one kind of product is mostly common. This distribution follows the power law. Fig. 6 shows the distribution of the number of order on the product. Most products are ordered only once. Products which is ordered many times is fewer.

In Fig. 6, the most popular product is arranged in the origin and the most unpopular one is arranged to the most right hand side on the horizontal axis. Other products are arranged from the popular one to unpopular one. Fig. 7 shows the distribution on the

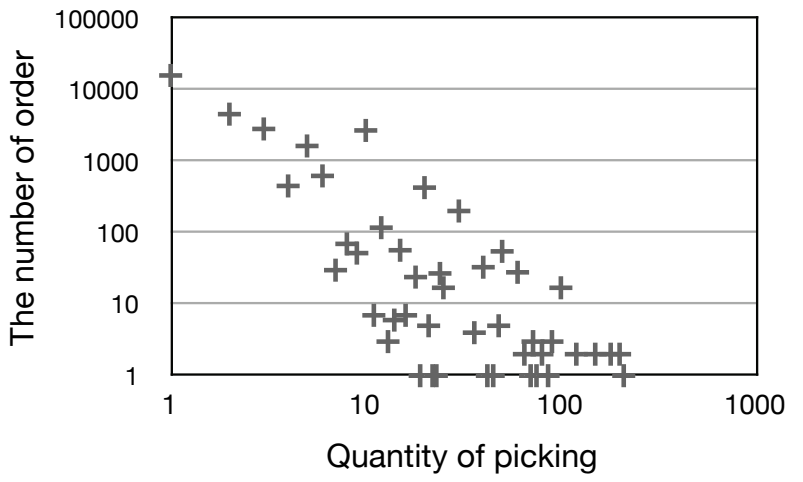

Fig. 7 The number of order by quantity of picking

number of order and the total picking times of products per one order. This chart shows most of order includes only one product for one kind of product per one order (the worker picks only one product for one kind of product).

These results show that the logistic center stores many kinds of product with a few numbers. However, there are some products, which are very popular and must keep them a very large number of them. In general, these product number distributions in the logistic center are often observed such as Amazon com. So, the logistic center needs a huge floor area but super markets.

\section{Numerical Experiments}

The effectiveness and validity of the proposed method are examined by using the actual logistic center model and order sheets' data. In order to verify the efficiency, we compare the proposed method with First In First Out (FIFO) method. FIFO is a rule to determine the workers' picking priority and this rule is that workers arrived first can work preferentially on the shelves.

The logistic center model is shown in the Fig. 4 and experimental condition is shown the Table 3 . Characteristics of order sheet' data is shown in Figs. 57. We compare the makespan between a random method, FIFO method and the proposed method by changing the number of workers. The random method is that the worker is randomly selected when workers jamming occurs at the same shelf. Fig. 8 shows makespans vs the number of workers. Fig. 9 shows traveling time per worker vs the number of workers. A few jamming occurs for a few workers. It hardly make the waiting time on the shelves by FIFO schedule. Furthermore, the makespan becomes shorter as the number of workers becomes large, but it converges due to jamming though the traveling time becomes shorter in Fig. 9. Fig. 10 shows an improvement rate by the proposed method of the number of workers. These results show appropriate number of workers appear in this condition. 


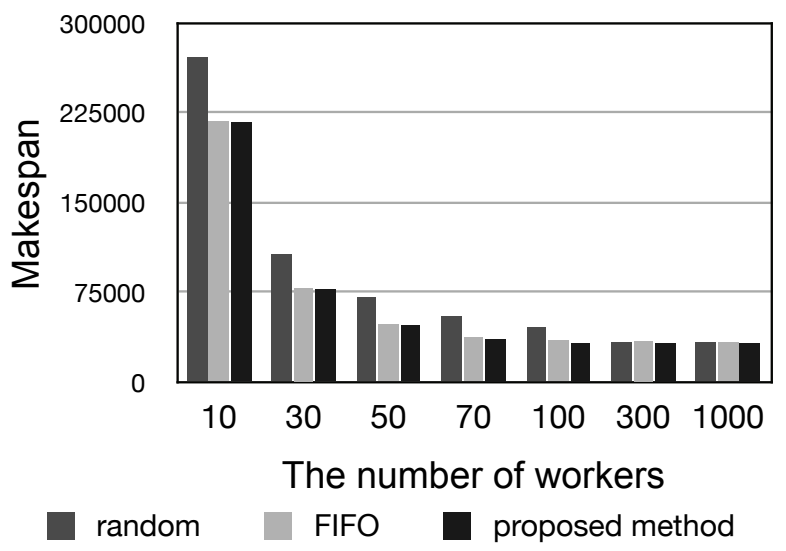

Fig. 8 The makespan with each number of workers

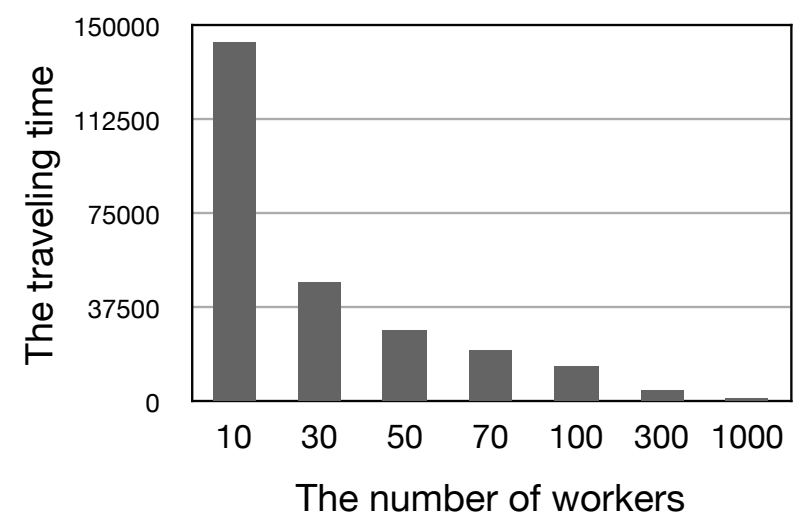

Fig. 9 The traveling time per worker

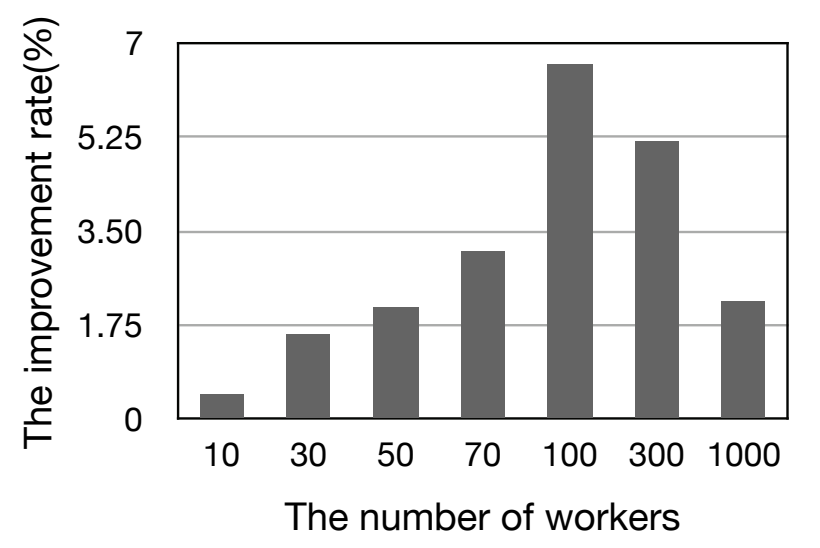

Fig. 10 The improvement rate of the proposed method with each number of workers

\section{Concluding Remarks}

This study proposes the new method for an orderpicking problem. The proposed method can deal with the order-picking problem with workers jamming restrictions by transforming the order-picking problem to a job-shop problem. LCO is applied to not only determining the shelves priority for workers' task but also solving the transformed JSP. Results show the proposed method brings better solutions than the random method and rule-based method do. This rulebased method means that the first coming worker can pick products at first when workers' jamming occurs at some self. Furthermore, we find there exists the suitable number of workers in the modeled logistic center in experiments. This means we can employ the suitable number of workers for the specific logistic center in simulation. In future work, we experiment on other conditions of the logistic center model. In the case of the small number of shelves, the proposed method becomes more effective for the large number of workers because of the more jamming situation. We need to find the suitable number of workers on the variety condition.

\section{References}

[1] M. Watanabe, M. Furukawa and Y. Kakazu: Evolutionary computation approach to a logistic CIM scheduling problem; Flexible Automation and Intelligent Manufacturing (FAIM'98), Bengell House, inc., ISBN:1-56700-118-1, pp. 759-770 (1998)

[2] M. Furukawa, Y. Kajita, A. Mizoe, M. Watanabe, I. Suzuki and M. Yamamoto: Self-Organization Stock Assignment for Large-Scale Logistic Center, Intelligent Autonomous System 10, Burgard et al. (Eds.), IOS Press (2008), pp. 164-172, ISBN 9781-58603-887-8, Library of Congress Control Number 2008929931

[3] M. K. Liu: Clustering techniques for stock location and order-picking I a distribution center; Computers E Operation Research, Vol. 26, pp. 989-1002 (1999)

[4] M. B. Rosenwein: An application of cluster analysis to the problem of locating items within a warehouse; IIE Transaction, Vol. 26, No. 1, pp. 101-103 (1994)

[5] J. M. Jarvis and E. D. MacDowell: Optimum product layout in an order picking warehouse; IIE Transactions, Vol. 23, No. 1, pp. 93-102 (1991)

[6] M. A. Hariga and P. L. Jackson: The warehouse scheduling problem: formulation and algorithm; IIE Transactions, Vol. 28 (1996)

[7] L. C. Tang and E. P Chew: Order picking system: Batching and storage assignment strategies; Computers ind. Engng, Vol. 33, Nos. 3-4, pp. 817-820 (1997)

[8] C. G. Peterson II and R. W. Schmenner: An evaluation of routing and volume-based storage policies in an order picking operation; Decision Science, Vol. 30, No. 2, pp. 481-501 (1999)

[9] M. Furukawa, M. Watanabe and Y. Matsumura: Local clustering organization (LCO) solving a largescale TSP; Journal of Robotics and Mechatronics, Vol. 17, No. 5, pp. 560-567 (2005)

[10] M. Furukawa, Y. Matsumura and M. Watanabe: Development of local clustering organization applied to job-shop scheduling problem; Journal of the Japan Society for Precision Engineering, Vol. 72, No. 7 (2006) 


\section{著者略歴}

岩禧等等

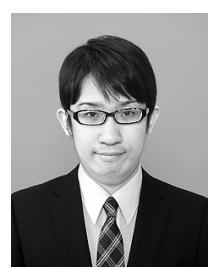

2011 年北海道大学工学部情報エレクト ロニクス学科卒業, 同年 4 月同大学院修士 課程となり，現在に至る。組合せ最適化問 題，大規模物流センターにおけるピッキ ングスケジューリングに関する研究に従 事. 工学学士。機械学会, 情報処理学会, 精密工学会の各学生会員.

鎝香竖旉

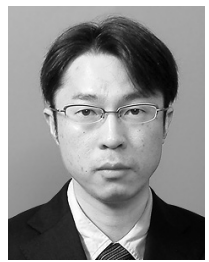

1999 年北海道大学工学部情報工学科卒 業, 2004 年北海道大学大学院工学研究科 博士後期課程修了 . 同年室蘭工業大学サテ ライト・ベンチャー・ビジネス・ラボラト リー中核的研究機関研究員. 2007 年北海 道大学大学院情報科学研究科助教, 2012 年北見工業大学情報システム工学科准教授となり, 現在に至 る.複雑系工学, web マイニングによる感性情報の抽出など に関する研究に従事し，行動生成における振動子型神経回路 の研究も行う. 博士 (工学) . 情報処理学会, 日本ロボット 学会, 精密工学会, 日本感性工学会の各会員.
蛙毕雅热

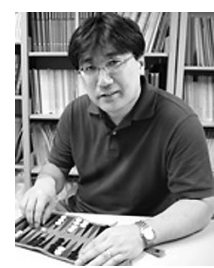

1996 年北海道大学大学院工学研究科シ ステム情報工学専攻博士後期課程修了.同 年日本学術振興会特別研究員 (PD) . 1997 年北海道大学大学院工学研究科助手, 2000 年同大学院工学研究科助教授, 同大学院 情報科学研究科助教授, 2007 年同大学院 准教授を経て , 2012 年同大学院教授. この間, 科学技術振興 機構さきがけ研究員, デューク大学客員研究員を兼務. 現在 は, メタヒューリスティクス手法, 進化型計算にもとづく仮 想ロボット開発, 複雑ネットワークの研究に従事. 博士 (工 学). 情報処理学会, 電子情報通信学会, 人工知能学会, 計 測自動制御学会, 日本オペレーションズ・リサーチ学会, 精 密工学会, 日本機械学会などの各会員 .

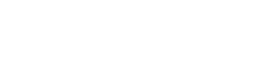

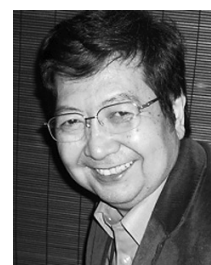

1973 年北海道大学大学院工学研究科修 士課程修了. 同年旭川工業高等専門学校 電気工学科助手, 同機械工学科助教授, 同 制御情報工学科教授を経て，2006 年北海 道大学大学院情報科学研究科教授. この 間, コーネル大学 NSF 研究員, イースト アングリア大学客員教授，1981 年工学博士 (北海道大学). 自律分散システム，インテリジェント・エンジニアリング, 複雑ネットワークなどの研究に従事.計測自動制御学会, 機 械学会 (フェロー), 精密工学会の各会員 . 